Vol 4. No 1. Februari 2020

ISSN 2580-5029

\title{
Spatial Distribution and Morphology Character of Podang Mangoes (Mangifera indica L.) from Five Sub-district in Kediri Regency, East Java, Indonesia
}

\author{
Aisyah Hadi Ramadani ${ }^{*}$, Muhammad Riza Firdausi², Rasyadan Taufiq Probojati ${ }^{2,3}$, \\ Ahmad Affan Ali Murtadlo 3 \\ ${ }^{1}$ Division of Ecology, Generasi Biologi Indonesia (GENBINESIA) Foundation, Jl. Swadaya Barat No. \\ 4 Gresik, 61171, East Java, Indonesia \\ 2Depatment of Biology, Faculty of Mathematics and Science, State University of Malang, Jl. \\ Semarang No.5, Lowokwaru, Malang, 65145, East Java, Indonesia. \\ ${ }^{3}$ Division of Genetics and Molecular Biology, Generasi Biologi Indonesia (GENBINESIA) Foundation, \\ Jl. Swadaya Barat No. 4, Gresik, 61171, East Java, Indonesia \\ *aisyahramadani@genbinesia.or.id
}

\begin{abstract}
This study objectives to determine the distribution maps and identify the morphological character of local Mango Podang at five sub-districts in Kediri. This research used purposive sampling method for collecting data. Coordinate of local mango was analyzed using QGIS software version 3.6. Morphological characters are examined by observing the morphology. Microclimate factors that were measured are altitude, intensity, temperature and moisture of soil and air, soil $\mathrm{pH}$, and soil nutrient. Morphological characters were analyzed for homogenity by statistical test. The results showed that Mango Podang distribution has spread in residential areas and has different altitude factors between 85-459 meters above sea level. The total population(individu/400m²) found in this study were Mojo 10 (11.2\%), Banyakan 17 (19.1\%), Grogol 8 (9\%), Semen 3 (3,4\%) and Tarokan 51 (57.3\%). Mangga Podang of Kediri Regency generally have homogenous morphological characters, but there were the special character which differs each other, they are the number of flowers in 1 panicle, the weight of ripe fruit and exocarp color of ripe fruits. This morphological variation dependent to light intensity, altitudinal, the velocity of wind and soil nutrient factors.
\end{abstract}

Keywords: Spatial distribution, morphology character, Mango Podang local, altitude factors

\section{INTRODUCTION}

Indonesia is one of the centers of interand intra-specific Mangifera diversity in Southeast Asia (Mukherjee, 1972). There are around 250 varieties of mangoes available on Sumatra, Kalimantan, Java and West Nusa Tenggara. However, only about 57 varieties are utilized and cultivated by the local people
(Sumiasri et al), 2006; Uji, 2007). Mango in rural areas, is often used for additional income to the community where the plants are often planted in the yard or in the garden (Andri et al., 2013). This is supported by the priority of the Indonesian government regarding on of the popular local plants 
horticultural, viz. banana, orange, mango, etc (Setijati et al., 1987).

Nowadays, there is a rapid erosion of genetic diversity along with the reduction in the type of cultivated mangoes. This is compounded by the decreasing distribution area which is now used for residential land. In addition, imported types of mangoes are sold at cheap prices from local species, so people prefer to cultivate mangoes that have higher economic value (Sumiasri et al., 2006). This will greatly affect the distribution of podang mangoes in the Kediri area.

Kediri is an area that is mostly lowland ( $\pm 67 \mathrm{~m}$ above sea level). Kediri area is an area that is well-known as a producer of Podang mangoes, especially in the districts of Banyakan, Tarokan, Grogol, Mojo, and Semen (Baswarsiati et al., 2007). Podang mango belongs to the Anacardiaceae family which is a seasonal fruit from around October to November. This mango has specific properties that are superior to other mangoes, which has a red-orange skin color, attractive yellow flesh color, sweet taste and strong, distinctive aroma, high water content, and has smooth fibers (Baswarsiati et al., 2007). This is in accordance with requests from Japan, Korea and Singapore who prefer mangoes that have an attractive appearance.

This great potential of podang mangoes, especially in the high economic aspects, it is necessary to study the distribution information of podang mangoes. However, there is currently no information about spatial distribution and morphological data from podang mangoes in the Kediri area. Spatial analysis makes it possible to obtain data that can be used to estimate the identification of plant names that grow in close area, overlapping or specific places. While morphological data can be used as a basis for understanding the conservation of local mango germplasm in the Kediri area.

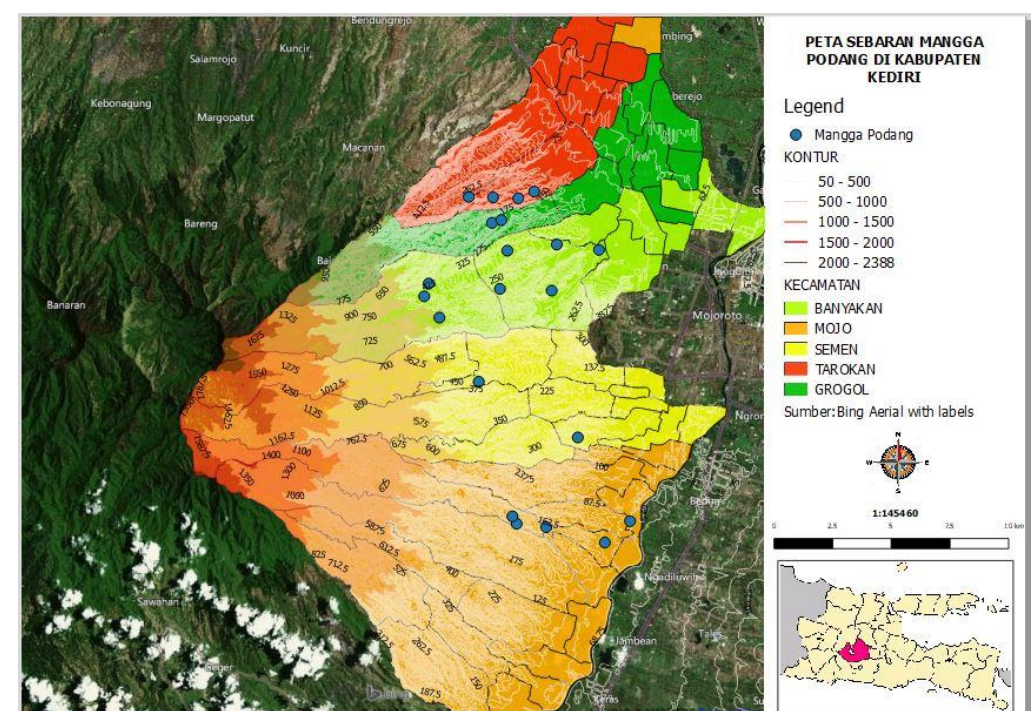

Figure 1. Spatial map of Podang Mangoes Tree Distribution on five district Banyakan, Mojo, Semen Tarokan and Grogol, Kediri (source: personal document) 
This is an initial step as an effort in conservation and development as well as exploring the benefits and potential. For this reason, research is needed to deftermine the current spatial distribution of podang mangoes in the Kediri area.

\section{METHODS}

This research as descriptive qualitative study that correlate the spatial distribution and morphological characteristics of podang mangoes trees which taken from five district namely Semen, Mojo, Banyakan, Grogol, and Tarokan in Kediri. The mangoes tree for morphological study was sampled by purposive sampling method based on the geographical administrative. Sampling was carried out to measure parameters including morphology traits of stems, leaves, flowers, and fruit in each location, as well as microclimate factors such as altitudinal, light intensity, air temperature and humidity, soil temperature and humidity, soil $\mathrm{pH}$ and also the nutrients. Morphological characteristic data published in earlier study (Ramadani et al., 2017).

\section{Distribution Mapping}

Spatial mapping of podang mangoes in five districts described their distribution horizontally and vertically. Horizontal distribution can be seen from the area which covered by podang mangoes trees based on administrative division. Vertical distribution trace the initial altitude where the mangoes tree firstly found to the last altitudinal height it can grows and able to adapt with the environment surrounded. The coordinates of site encounter are recorded using GPS.

\section{Data Analysis}

Morphological traits analysed by scoring refer to Fitmawati, et al.,(2013) and Bartlett test to examine the distinct appearance of each mango at each location. Clustering similarity among mangoes from five location described the correlation among morphological traits and microclimate parameters. The correlation was analysed using Principle Component Analysis (PCA) by MINITAB 15. The relation of morphological traits of Mango to their spatial distribution was mappedusing QGIS software version 3.6.

\section{RESULTS AND DISCUSSION}

This research succeeded in mapping the location of Podang mango distribution centers in five districts of Kediri The horizontal distribution shows that Podang mangoes grow in all these areas (Figure 1). Each region has a different number of distribution centers. The most distribution centers are Banyakan (8 locations), then Mojo (6 locations) and Tarokan (4 locations). The even distribution of podang manngga trees in Banyakan is caused by community planting activities in the area which make podang mangoes as plants in the yard. Mangoes cultivation in a wide area are not found in this area. In contrast to the distribution of podang mangoes in Mojo and Tarokan, where podang mango trees are more widely planted 
in large area and also concentrated at certain points. Spatial data is corroborated by the calculation of mango population obtained per $400 \mathrm{~m}^{2}$, namely Tarokan with 51 individuals (57.3\%), Banyakan 17 individuals (19.1\%), Mojo 10 individuals (11.2\%), Grogol 8 individuals (9\%), and Semen 3 individuals (3.4\%). Podang mangoes population is very high due to physicochemical factors that support the growth and development of mango trees, one of which is light intensity and wind speed. Light affects the formation of chlorophyll, photosynthesis, phototropism, and photo-periodism which determine the speed of plant growth(Rahajeng, 2015). Wind speed determines the speed of flowering, fertilization, and fruit development. The area with the fastest flower and fruit development is in Tarokan with the highest wind speed (Table 2).Mango plantations in Tarokan are on ahilly topography with rare canopy cover of other plants so that exposure to wind and light is optimal (Table 2).

\section{Spatial Observation}

Observation of the vertical distribution of podang mangoes trees based on altitude was successful recorded that the podang mangoes was spread over an altitude range of 85 - 552 above sea level (asl). The lowest point in the area of the Mount Wilis is in the Mojo and the highest in the Semen. Podang mangoes in most areas are spread from a height of 123-459 asl, in Mojo 85-374 asl, Semen 151-552 asl, Tarokan 141-298 asl, and Grogol 211-217 asl. The altitudinal places creates an optimal growing and developing environment. The results of this study are consistent with the statement of former research (Fitmawati and Hayati, 2018) that mangoes are plants that grow well in lowland wet tropical forests with the highest distribution in lowland areas below $300 \mathrm{~m}$

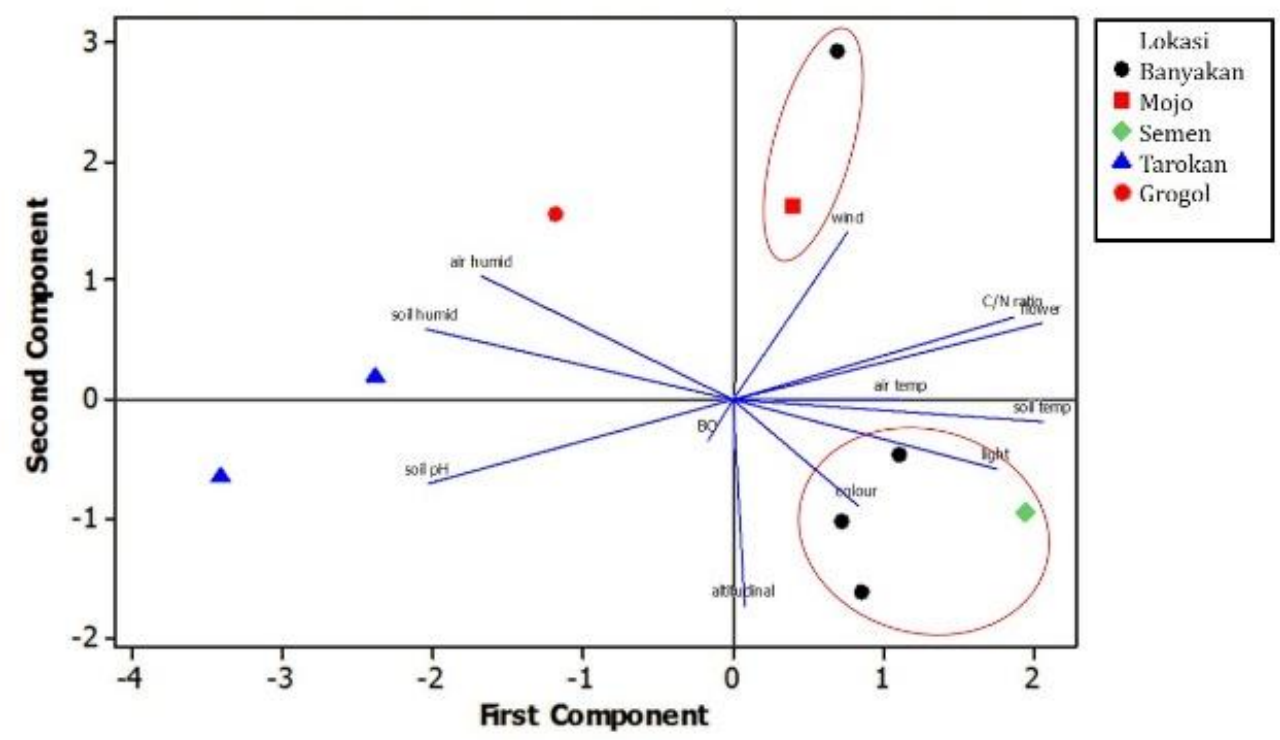

Figure 2. Principle component analysis of morphology traits and microclimate correlation 
altitude. The height of the place determines the presence of mango plants by weatherfactors, air temperature, and soil conditions (Ramadani, 2017; Ewusie, 1990; Anwar et al., 2011). The higher place, the lower air temperature, with wet weather, and high soil moisture so that mango trees are rarely found above 1000 asl.

\section{Morphological characteristics}

Spesific morphological traits that distinct among podang mangoes from five district described in Table 1. Morphological data obtained from (Ramadani et al., 2017) measurements noted that there were significant differences ( $p$-value $<0.05$ ) in the characteristics of podang mangoes in number of flowers in 1 panicle and fruit characteristics (Table 3). This difference is a form of adaptation developed by each plant according to the microclimate conditions in the environment around the tree(Table 1,2).

The analysis showed that there were 2 groupings of morphological characters. This grouping is based on the similarity of morphological characteristics. Podang mangoes that grow in the Banyakan area cluster with Semen. There is 1 sample from Banyakan that is similar to Mojo. Podang that grows in Tarokan has morphological characteristics that are different from other locations. The main differentiating factors appear in the characteristics of fruit (color and size), flowers (number of panicles). This character correlate to its physicochemical parameter as microclimate. The most determining factor of this morphological characteristic is soil nutrient, wind, and light intensity (Figure 2) (Stevovic et al., 2010; Vieccelli et al., 2016).

Table 1. Morphological Characteristic of Podang Mangoes In Five Location

\begin{tabular}{|c|c|c|c|c|c|c|}
\hline No & Morphology traits & Banyakan & Tarokan & Mojo & Semen & Grogol \\
\hline 1 & Young leaf ratio & 4.8 & 2.7 & 2.8 & 2.5 & 2.9 \\
\hline 2 & $\begin{array}{l}\text { Young leaf branch } \\
\text { ratio }\end{array}$ & 3.9 & 2.5 & 4.3 & 4 & 2.7 \\
\hline 3 & Young leaf colour & $\begin{array}{l}\text { Green } \\
\text { brownish }\end{array}$ & $\begin{array}{l}\text { Green } \\
\text { yellowish }\end{array}$ & Light Green & Light green & Light green \\
\hline 4 & $\begin{array}{l}\text { Number of flower } \\
\text { in } 1 \text { panicle }\end{array}$ & 21 & 20 & 25 & 20 & 20 \\
\hline 5 & $\begin{array}{l}\text { Colour of } \\
\text { pedunculus }\end{array}$ & $\begin{array}{l}\text { Light red } \\
\text { yellowish }\end{array}$ & Light red & Light red & Light red & Light red \\
\hline 6 & Colour of Corolla & $\begin{array}{l}\text { Red violet } \\
\text { yellowish }\end{array}$ & Red violet & Red violet & Red violet & Red violet \\
\hline 7 & $\begin{array}{l}\text { Colour of fruit } \\
\text { exoocarp }\end{array}$ & Yellow redish & $\begin{array}{l}\text { Orange } \\
\text { reddish }\end{array}$ & Yellow & Yellow & Yellow \\
\hline 8 & $\begin{array}{l}\text { Colour of fruit } \\
\text { mesocarp }\end{array}$ & Yellow - orange & $\begin{array}{l}\text { Orange } \\
\text { reddish }\end{array}$ & Orange & Dark orange & Orange \\
\hline 9 & $\begin{array}{l}\text { Water contain in } \\
\text { fruit }(\%)\end{array}$ & 90.9 & 85.27 & 90.9 & 91.8 & 80.8 \\
\hline 10 & Fruit aromatic & Sweet & Sweet-acid & Sweet & Sweet & Sweet \\
\hline
\end{tabular}


Biotropic 2020 Vol.4 (No.1): 1- 7

Spatial Distribution and Morphology Character of Podang Mangoes (Mangifera indica L.) from Five Subdistrict in Kediri Regency, East Java, Indonesia

Table 2. Microclimate around Podang mango trees in five location

\begin{tabular}{lcccccccccc}
\hline Location & $\begin{array}{c}\text { Altitudin } \\
\text { al (asl) }\end{array}$ & $\begin{array}{c}\text { Light } \\
\text { intensity } \\
(\mathbf{l u x})\end{array}$ & $\begin{array}{c}\text { Wind } \\
\text { Speed } \\
\mathbf{( m / s )}\end{array}$ & $\begin{array}{c}\text { Air } \\
\text { Temp } \\
\left({ }^{\circ} \mathbf{C}\right)\end{array}$ & $\begin{array}{c}\text { Air } \\
\text { Humidity } \\
\mathbf{( \% )}\end{array}$ & $\begin{array}{c}\text { Soil } \\
\text { Temp } \\
\left({ }^{\circ} \mathbf{C}\right)\end{array}$ & $\begin{array}{c}\text { Soil } \\
\text { Humidity } \\
(\%)\end{array}$ & $\begin{array}{c}\text { Soil } \\
\text { pH }\end{array}$ & $\begin{array}{c}\text { C/N } \\
\text { ratio }\end{array}$ & $\begin{array}{c}\text { BO } \\
\text { (\%) }\end{array}$ \\
\hline Banyakan & $122-459$ & 723 & 0.65 & 33 & 59 & 27 & 55 & 7 & 14 & 2.83 \\
Tarokan & $141-298$ & 790.85 & 1.63 & 32 & 53 & 29 & 37 & 6.7 & 16 & 2.52 \\
Mojo & $85-374$ & 724 & 1.08 & 30 & 65 & 25 & 62 & 7 & 13 & 2.08 \\
Semen & $151-552$ & 628 & 1.10 & 25 & 52 & 27 & 48 & 7 & 14 & 2.99 \\
Grogol & $211-217$ & 516 & 1.45 & 27 & 74 & 25 & 75 & 7 & 14 & 2.74 \\
\hline
\end{tabular}

Table 3. Bartlett test of the morphological characteristic

\begin{tabular}{lll}
\hline \multicolumn{1}{c}{ Morphology traits } & \multicolumn{1}{c}{ Mean } & P-value \\
\hline Young leaf ratio & $3.64 \pm 2.12$ & 2.48 \\
Young leaf branch ratio & $3.48 \pm 0.81$ & 4.09 \\
Young leaf colour & $2.22 \pm 1.39$ & 0.63 \\
Number of flower in 1 panicle & $21.2 \pm 2.16$ & $0.00^{*}$ \\
Colour of pedunculus & $1.56 \pm 0.51$ & 0.19 \\
Colour of corolla & $1.78 \pm 0.90$ & 1.68 \\
Colour of fruit exocarp & $1.56 \pm 0.52$ & 0.15 \\
Colour of fruit mesocarp & $1.78 \pm 0.09$ & $0.02^{*}$ \\
Water content in fruit & $87.93 \pm 4.75$ & 0.21 \\
Fruit aromatic & $1.33 \pm 0.70$ & 1.83 \\
\hline
\end{tabular}

\section{CONCLUSION}

This research concluded that the spatial distribution in Podang mangoes in five district, Kediri is determine by antropogenic aspect, the highly number population of Podang exist in Tarokan, but the widest area occupy is Banyakan depend on cultivation area. It distribute in lowland are at range 85662 above sea level altitudinal place. There is several differencies of morphological characteristic of podang in five location which affected by microclimate surrounded, soil nutrient, and altitudinal of places. The number of flowers in 1 panicle, the weight of ripe fruit and exocarp color of ripe fruits are specific character for each podang mangoes in five location.

\section{ACKNOWLEDGMENTS}

We would like to say thank you to Generasi Biologi Indonesia as our affiliation that support our research operational and publication. Sincere thanks also dedicated to our colleagues Mahendra Putra Tama for all the technical assistance and valuable discussions during the study.

\section{REFERENCES}

Andri, K.B, M. Winarno, and P.B. Daroini. (2013) "Characteristic of Mango Diversity in East Java: Case Study in Tiron, Kediri", Proceeding International Conference The 4th Green Technology Faculty of Science and Technology Islamic of University State Maulana Malik Ibrahim Malang, 127-131.

Anwar R, Saheed A, M. Yaseen, W Ahmad, and M. Nafees. (2011) "Bimonthly Nutrient Application Programme On Calcareous Soil Improves Flowering And Fruit Set In Mango (Mangifera Indica L.)", Pak. J. Bot., 43(2): 983-990. 
Baswarsiati and Yuniarti. (2007) "Karakter Morfologis dan Beberapa Keunggulan Mangga Podang Urang (Mangifera indica L.)", Buletin Plasma Nutfah 13 (2): 62-69

Ewusie. (1990) Pengantar Ekologi Tropika. Yogyakarta: Kanisius.

Fitmawati and I Hayati. 2018) Mangifera of Sumatra. Pekanbaru: University Riau Press. pp.19-46

Fitmawati, A Swita, N Sofyanti, Herman. 2013. Analisis Kekerabatan Morfologi Mangifera dari Sumatera Tengah. Floribunda 4 (7):169-174

Mukherjee, SK. (1972) "Origin of the mango (Mangifera indica L.)", Economic Botany, 26: 260-264.

Rahajeng A.R.P.(2015) "Pengaruh Faktor Abiotik terhadap Hubungan Kekerabatan Tanaman Sansiviera trifasciata L". Jurnal Biota 1:1.

Ramadani, A H and N. Istiqomah.(2017) Prosiding Seminar Nasional Hayati V, 136-142.

Setijati, D. Sastrapradja, and M.A. Rifai. 1987) Mengenal Nusantara Melalui Kekayan Floranya. Bogor: Komisi Pelestarian Plasma Nutfah Nasional.

Stevovic S, V S Mikovilovi, and D AliDragosavac. (2010) "Environmental impact on morphological and anatomical structure of Tansy", African Journal of Biotechnology 9 (16): 2413-2421.

Sumiasri, N., J. Rijadi, and D. Priadi. (2006) "Variasi Jenis dan kultivar mangga di Madiundan sekitarnya; Perkembangan dan Permasalahannya", Biodiversitas 7 (1): 39- 43.

Uji, T. (2007) "Review: Keanekaragaman JenisBuah-Buahanasli Indonesia danPotensinya", Biodiversitas, 8 (2): 157167.
Vieccelli J C, D L D Siquera, W M D S Bispo, and L M C Lemos. (2016) Characterization Of Leaves And Fruits Of Mango (Mangifera Indica L.) Cv. Imbu, Rev. Bras. Frutic., Jaboticabal - SP 38(3): 1-19. 